\title{
People living with AIDS/HIV in Botswana: a needs assessment
}

\author{
A Zuyderduin, D Litt et Phil student \\ University of South Africa and Lecturer Department of Nursing, Aga Khan University, Kampala, Uganda
}

\author{
VJ Ehlers, \\ Senior Lecturer, Department of Health Studies, University of South Africa
}

DM van der Wal,

Senior Lecturer, Department of Health Studies, University of South Africa

Keywords: HIV/AIDS in Botswana, Maslow's Hierarchy of Needs, needs assessment, people living with AIDS/ HIV

List of abbreviations used throughout this article :

AIDS - acquired immune deficiency syndrome

ART - anti retroviral therapy

ARV - anti retroviral

COCEPWA - Coping Centre for People Living with HIV/AIDS

DOTS - directly observed treatment strategy (for taking anti-TB medication) HIV - human immune deficiency virus NACA - National Aids Co-ordinating Association

PLWA/H - people living with AIDS/HIV UNAIDS - United Nations Program on HIV/AIDS

\section{Correspondence address:}

DrV Ehlers

Department of Health Studies

University of South Africa

POBox 392

Unisa, 0003

Tel : (012) 429-6731

Fax :(012)347-8287

E-mail : ehlervj@unisa.ac.za

\section{Abstract: Curationis 30(3): $x-y$}

A deficit in information and knowledge regarding people living with AIDS in Botswana, hampering health care planning and satisfactory health care delivery to these people, necessitated the needs assessment reported on in this paper. Not only did self-imposed alienation and societal levels of stigma surrounding HIV and AIDS force many people living with AIDS/HIV (PLWAH) into silence and denial of their HIV+ve diagnosis, thereby creating knowledge and information deficits. These same factors also pose challenges for conducting a needs assessment among these persons. Consequently, a 73 item questionnaire was administered to a convenience sample of 39 male and 77 female PLWAH in Botswana. Maslow's Hierarchy of Human Needs served as a general theoretical point of departure for the needs analysis and the 73 items represented needs at all levels of this hierarchy.

Analysis of the data indicates that $65 \%$ of the respondents lived in urban areas. The majority of individuals ( $42 \%$ ) were tested for HIV because they became ill, while $28 \%$ did so voluntarily. Other reasons for testing were: child becoming ill, partner becoming ill, being pregnant and having been raped. Only $7 \%$ indicated that their HIV status had been disclosed to other persons. With regards to love and belongingness $70 \%$ of the respondents indicated that they were not in an intimate relationship, nearly one third experienced multiple deaths within their families due to AIDS, $61 \%$ had access to a support group, and $48 \%$ had not informed their parents about their HIV+ve status. Stigmatisation weighed down self-esteem. Despite the deficiencies in the fulfilment of safety, belonging and esteem needs, positive attitudes were reported by $73 \%$ of the 116 PLWAHSs.

\section{Opsomming}

Ontbrekende inligting en kennis betreffende persone wat met VIGS/MIV lewe in Botswana, wat gesondheidsorgbeplanning en bevredigende gesondheidsorgvoorsiening aan hierdie mense benadeel, het die behoeftebepaling genoodsaak waaroor verslag gedoen word in hierdie artikel. Self-opgelegde vervreemding en sosiale stigmavlakke wat MIV en VIGS omgewe, dwing baie persone wat met VIGS/MIV lewe tot stilte en ontkenning van hulle MIV+we diagnose, waardeur ' $n$ gebrek aan kennis en inligting geskep word. Dieselfde faktore bied uitdagings om ' $n$ behoeftebepaling onder die persone te doen. Gevolglik is ' $n$ 73-item vraelys uitgedeel aan 'n gerieflike steekproef van 39 manlike en 77 vroulike persone wat met VIGS/MIV lewe in Botswana. Maslow's se Hiërargie van Menslike Behoeftes het gedien as die algemene teoretiese vertrekpunt om die behoeftebepaling te doen en die 73 items op die vraelys het al die vlakke van behoeftes in hierdie hiërargie verteenwoordig. 
Die analise van die data het aangedui dat $65 \%$ van die respondente in stedelike gebiede gewoon het. Die meerderheid van die invidue $(42 \%)$ was getoets vir MIV omdat hulle siek was, terwyl $28 \%$ vrywillig getoets is. Ander redes vir toetsing was: " $n$ siek kind, 'n siek gade, swangerskap, of verkragting. Sleg $7 \%$ het aangedui dat hulle MIVstatus bekendgemaak was aan ander persone. Betreffende liefde en groepsgebondenheid ("belongingness") het $70 \%$ van die respondente aangedui dat hulle nie betrokke was by ' $n$ intieme verhouding nie, bykans een-derde het veelvuldige sterftes in hulle families ervaar as gevolg van VIGS, $61 \%$ het toegang tot ' $n$ ondersteuningsgroep gehad, en $48 \%$ het nie hulle ouers ingelig oor hulle MIV+we status nie. Stigmatisering het hulle eie waarde ondermyn. Ten spyte van gebreke in die verwesenliking van die behoeftes betreffende veiligheid, groepsgebondenheid, en eie waarde, het $73 \%$ van die 116 persone wat met VIGS/ MIV lewe, positiewe houdings gerapporteer.

\section{Introduction}

In general, there is a growing appreciation of the importance of how health-service recipients feel about, and how satisfied they are with, the care and/or treatment they receive. However, the self-imposed and societal levels of stigma surrounding HIV and AIDS have forced people living with AIDS/HIV (PLWAH) into silence and denial of their HIV+ve diagnosis. This largely prevented contributions by the PLWAH to the quality of life and health care in the context of living with AIDS. Lack of information and knowledge about their needs, core functioning and wellbeing impede the development of quality health care and support, necessitating health care practitioners to base their services on what they deem appropriate. The situation is no different in Botswana and necessitated an analysis of the needs of PLWAH in order to render care to these people relevant to their own needs, rather than care based on the health care providers' perceptions. This paper reports the findings of a needs assessment conducted among PLWAH in Botswana

\section{Background information}

Botswana is a landlocked country located in the centre of southern Africa, sharing borders with South Africa,
Namibia and Zimbabwe. It has a population of 1.7 million, $40 \%$ of whom are younger than 18 years of age (Tlou, 1996:27). Botswana's economy is growing at a rate of $6.6 \%$, helping the government in its endeavours to address poverty issues. However, the HIV/AIDS epidemic, affecting $38.8 \%$ of the economically active population, has negative implications for current and future economic growth. An estimated 258000 citizens of Botswana, aged 15-49 years, are infected with HIV. The prevalence of HIV among pregnant women aged $15-49$ was, in 2000 , reported to be $35.4 \%$. Approximately one out of eight babies is infected with HIV at birth (NACA, 2002:49; UNDP, 2000:7). Projections indicate that by 2010 Botswana's children under 18 years of age who have lost one or both parents could range from 159000 to 214000 (UNDP \& Govt of Botswana, 2000:18-19).

Reports of rejection and social distancing of PLWAH have been common in Botswana (Bara, 2002:1-9; Donnelly, 2003:1-3; Tlou, 2002:654-663). Pleas for help by President Mogae (2000:13) and the report by Piot, Bartos, Ghys, Walker and Schwartlander (2001:968) about the scope and the devastating impact of the AIDS epidemic in Botswana and the region might discourage people and cause them to lose hope. However, there have been more optimistic studies as well, outside Botswana in the late 1990s, that investigated the link between levels of stigma and levels of motivation of PLWAH to lead positive lives inspired by hope and dreams for the future (Barroso \& Powell-Cope, 2000:340-353; Nannis, Patterson \& Semple, 1997:22; Swindells, Mohr, Justis, Berman; Squier, Wagener \& Singh, 1999:383-391). This secrecy about being HIV+ve has largely prevented contributions by the PLWAH to the definition of quality of life in the context of living with a life-threatening illness. This lack of information about their needs, core functioning and wellbeing as HIV+ve people influences the development of quality health care and support, since the care providers resort to offering services based on their perceptions as to what is right and/or best for PLWAH, without initial inputs and without continuous feedback from the PLWAH concerned.

\section{Problem statement}

There are large numbers of PLWAH in Botswana. No needs assessment has been documented which identifies the PLWAHs' needs as perceived by themselves in Botswana. Health care is provided to PLWAH in terms of the health care workers' perceptions about these needs. This survey attempted to identify the PLWA/Hs' needs as reported by themselves in responding to open and closed ended items in self completion questionnaires. Such data could then be utilised to design programmes to meet the PLWA/Hs' specific needs.

\section{Research design}

A survey design of low-cost was conducted over a time period of four months during 2000.

This survey explored the perceptions of the PLWAH concerning the quality of their lives, deficiency and being needs and whether the PLWAH pursued higher levels of well-being.

The motivation for this survey by and for PLWAH was to persuade the HIV+ve people to inform others about their needs and concerns and to help address some of the suffering caused by HIV and AIDS in Botswana.

\section{Research population}

The research population comprised all PLWAH in Botswana. However, as this is a hidden population in Botswana and as no census exists about this population, only HIV+ve persons who had told at least one other person about their HIV+ve status (usually the person who requested their participation in the needs assessment and handed them the questionnaire to be completed) could be included in the study population. Furthermore, each respondent had to be sufficiently proficient in English to be able to complete the questionnaire. This proved to be no problem as English is the official language of Botswana and all the respondents could read and write English and could understand the questions. The researcher's contact telephone numbers were supplied on the questionnaire in case any respondent wished to clarify any aspect or did not understand any question.

\section{Sampling procedure}

In order to gain access to an unknown, hidden population convenience sampling had to be used. Burns and Grove (2001:376-377) maintain that "... snowball sampling holds promise for locating samples that are difficult or impossible 
to obtain in other ways ... When the researcher has found a few subjects with the needed criteria, the subjects are asked for assistance in getting in touch with others who have similar characteristics". In this case, the PLWAH might not have bcen approachable by the researcher, and it could have been interpreted as being a breach of confidentiality if the person they confided in about their HIV+ve status shared this information with the researcher. Consequently, PLWAH known to the author through her involvement with the Coping Centre for People living with AIDS/HIV (COCEPWA) were requested to participate in the needs assessment by completing a questionnaire and to request any other PLWAH they might know of to do likewise. The geographical starting point for the snowball sampling procedure was thus the COCEPWA centre in Gaberone, the capital of Botswana. A total of 116 completéd questionnaires were returned to the researcher. All the respondents were HIV+ve, had disclosed their HIV+ve status to at least one other person, and could read and write English.

A non-random and convenience snowball sampling technique was thus employed, as informed by a review of previous studies of PLWAH. All those studies used non-random sampling methods (Bunting, 1996:64; Erlen \& Mellors, 1999:7; Ingram \& Hutchinson, 1999:93; Jirapaet, 2000:34; Kvitz, Crittenden, Madura \& Warnecke, 1994:191; Metcalfe, Langstaff, Evans, Paterson \& Reid, 1998:30; Murphy, Koranyi, Crim \& Whited, 1999:111). Snowball sampling techniques were used in these quantitative and qualitative studies, since truly representative samples were impossible to obtain due to the fact that this is a hidden population, which made it impossible to compile a census (Flaskerud, Lesser, Dixon, Anderson, Conde, Kim, Koniak-Griffin, Strehlow, Tullmann \& Verzemnieks, 2002:74-85). Since it is unlikely that marginalised groups such as the PLWAH will reveal themselves, one is generally unable to rely on probability samples, even if the whole population of a country could be identified (Platzer \& James, 1997:626).

\section{Research instrument}

Data were collected using structured questionnaires, in preference to face-toface interviewing, to protect the privacy of the PLWAH. It was perceived to be less threatening to complete questionnaires than to be tape-recorded during interviews or to participate in focus group discussions with other participants. Matched with the sampling techniques used, one advantage of this method was that a confidential study of a hidden population, who would otherwise not be identifiable, was possible. The PLWAH were unlikely to participate in a study that failed to guarantee their anonymity. The research assistants, both members of the Coping Centre for People with AIDS (COCEPWA), would not have encouraged other PLWAH to participate in any study unless it guaranteed total anonymity.

A 73-item questionnaire was used to survey the needs of a non-random convenience sample of 39 male and 77 female PLWAH in Botswana. Questions 1-31 asked about demographic variables, HIV testing and disclosure patterns. Questions 32-49 related to coping mechanisms, and questions 50-69 addressed support issues. The last four questions, 70-73, were questions about how the participants had generally felt during the month preceding the survey. In Section 4 of the questionnaire participants could record comments, suggestions and thoughts they might have had during or after answering the 73 questions (Zuyderduin, 2001:59-70). Contact telephone numbers were supplied in case any respondent wished to discuss any aspect with the researcher, or if any respondent wished to obtain further information about HIV/AIDS and/ or about COCEPWA

Each PLWAH completed the questionnaire and mailed it to the researcher. Through this survey, 116 PLWAH were approached to complete questionnaires; all 116 participants $(100 \%)$ returned questionnaires of which at least $90 \%$ of all items were completed and these were included in the survey's data analysis.

\section{Reliability and validity of the research instrument}

Previous studies on PLWAH posed the starting point for the selection of questions for the sections on stigma, discrimination, coping mechanisms used and support required by PLWAH. These questions were selected and evaluated against Maslow's Hierarchy of Needs to ensure that needs at all levels were included. The questions were submitted to members of COCEPWA, two nurse researchers and a statistician to evaluate the relevance of the questions to the potential needs of PLWAH. After consultations with a number of stakeholders, and especially with COCEPWA's members, potentially sensitive variables were deliberately excluded. These included questions about the number of sex partners during the preceding year, the age at sexual debut, suicide attempts and drug abuse.

The validity or the meaningfulness of the questionnaire was evaluated by piloting the questionnaire with members of COCEPWA. It was accepted that these persons had prior knowledge of particular problems as well as the range of likely responses, since they lived with the experience of being HIV+ve in Botswana. The five persons who participated in the pilot study were excluded from participation in the actual study. As this was the first attempt to identify PLWAH' needs in Botswana, the research results can only be accepted as a departure point for future studies. These exploratory questions will need to be followed up by higher order questions, more rigid quantitative research controls, and probably also by qualitative research in order to explore specific variables in depth.

\section{Data analysis}

The data from the completed questionnaires were translated into numerical codes to allow computer-based analysis, using the Epi-Info computer program. The nominal data were classified and cross-classified using frequencies. The ordinal data were rankordered and percentages were calculated for the variables. The relationships between certain variables and their effects on positive living, and thus on the needs of PLWAH in Botswana, were further explored statistically.

\section{Scope and limitations of the survey}

No generalisations were made from the sample to the entire population since the sample $(\mathrm{n}=116)$ was a small snowball (convenience) sample representing persons who shared information about their HIV+ve status with at least one person at COCEPWA. Thus the results might not be generalisable to PLWAH who had not yet shared the information about their HIV+ve status with another 


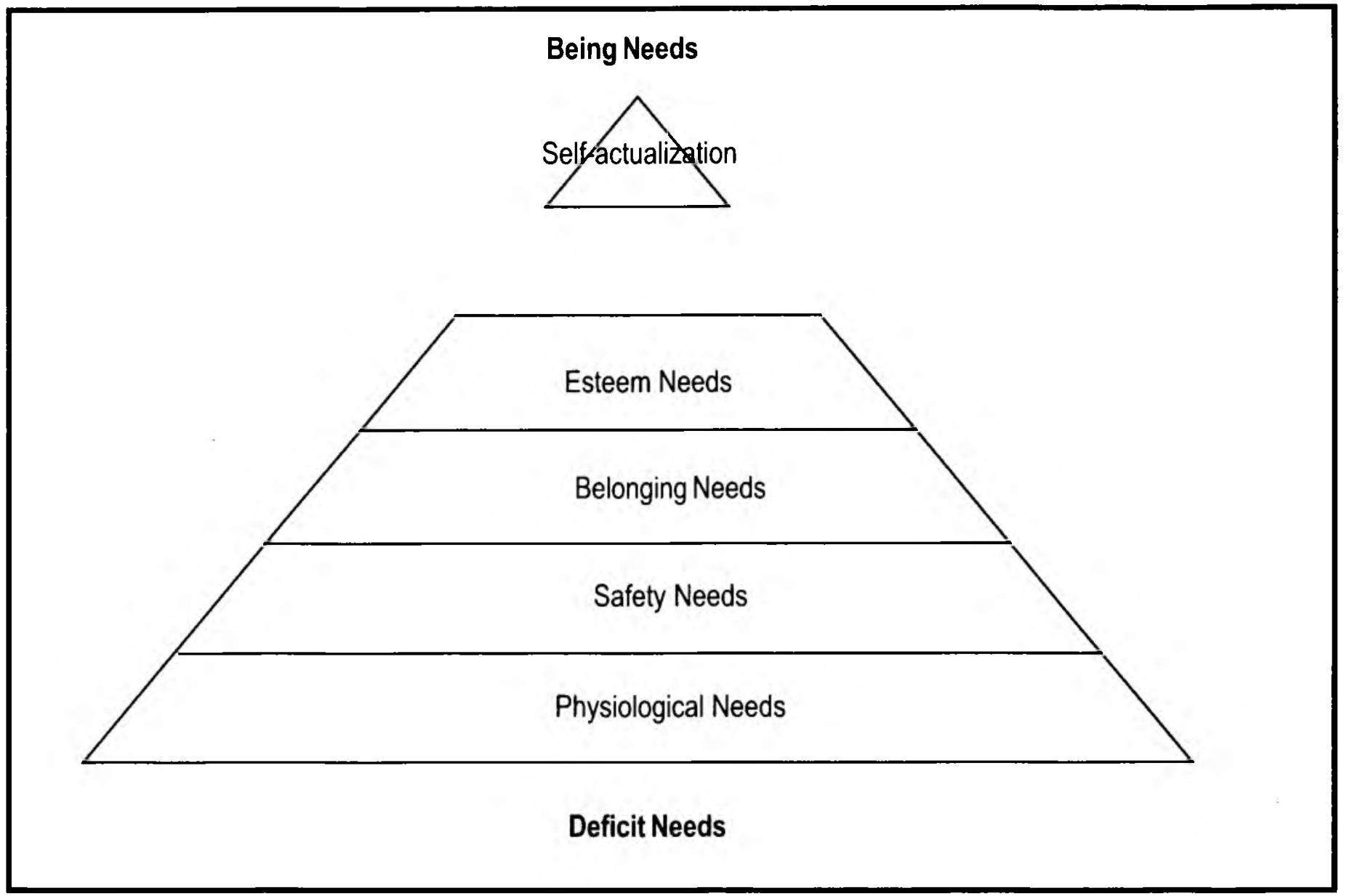

person, or who had no contact with COCEPWA members, or who were unable to complete questionnaires.

\section{Ethical considerations}

The ethical issues pertinent to this survey related to whether or not "... individuals or communities may be helped or harmed by the conduct, publicity and results of the research"'(Bowser \& Sieber, 1993:82). According to these authors it is a prerequisite for research on populations that are stigmatised to empower participants and get them to identify with the goals of the research. The participating PLWAH were accepted as peers for their experience and knowledge, and the survey provided them with an opportunity to make a genuine contribution towards enabling the health care services in Botswana to meet their needs as perceived by themselves, not by health care providers.

\section{Informed consent}

Discussions were held with members of COCEPWA who were willing to share insights, knowledge and experiences throughout the research process. Open communications were maintained with COCEPWA throughout the needs assessment, providing debriefing about the nature, findings and value of the research, were essential components for obtaining informed consent.

The respondents knew that the needs assessment was based on the approval and support of their peers, as represented by COCEPWA. Each respondent was free to participate or to refuse participation by refusing to complete the questionnaire.

Each PLWAH also had the right to terminate participation at any stage of completing the questionnaire, or not to answer specific questions. The PLWAH exercised these rights, explaining why different totals are reflected for different questions in the data analysis.

\section{Anticipated benefits}

Nobody was paid for completing questionnaires. The anticipated benefits included that the PLWAH had an opportunity to express their needs as perceived by themselves and thereby to help themselves, their peers and the health care workers to provide services geared to meeting their own needs, rather than their health care needs as perceived by and interpreted by the health care workers.

\section{Anonymity}

Questionnaires were handed out by members of COCEPWA who knew PLWAH. The anonymously completed questionnaires were posted to the researcher. Thus the researcher did not know who received questionnaires and the members ofCOCEPWA did not know who completed and/or returned questionnaires to the researcher. No follow-np procedures were used as that might have destroyed the anonymity of the respondents. The answers given to the specific items in the questionnaire were not identifiable to specific persons in the research report.

\section{Theoretical framework used to contextualise data}

Maslow's Hierarchy of Needs Theory was used as a theoretical point of departure and as a structural guide to ensure that all levels of human needs were addressed by the questionnaire.

The Hierarchy of Human Needs Theory maintains that lower order needs necessitate satisfaction before higher 
order needs can emerge or be satified. Lower "deficiency" needs are dependent on actions by other people and include physical, safety, belonging and esteem needs (Maslow, 1999:168-169).

The higher "being" needs, according to Maslow, are not dependent on other people but are met from within a person (Maslow, 1999:168-169). These needs for love, social justice, dignity and the like are basic to the growth and development of all people who aim to use all their qualities to reach higher levels of being throughout their lifetime. In the case of the PLWAH, actions such as joining support groups and providing care and support to their peers illustrated their desire to fulfil higher needs.

\section{Research results}

The research results, obtained from a computerised analysis of the completed questionnaires' data, as analysed with the Epilnfo program, will be presented in relation to the major sections of the questionnaire.

\section{Biographic information}

COCEPWA Gaborone was the starting point of the referral chain for this nonrandom sample. The urban centres of Gaborone and Francistown comprised $65 \%$ of the sample. Of the rest of the PLWAH, 26\% lived in villages and another $10 \%$ lived in remote rural areas. In Botswana PLWAH, when suffering illhealth, often move away from the urban areas and rent out their town houses/ rooms to generate income to help them subsist in the rural areas (Zuyderduin, 2001:28).

For every two women who participated in the needs assessment, one man participated. This was not representative of the overall ratio of male to female HIV and AIDS cases in Botswana, which is estimated to be $1: 1$. The pattern of both men and women being infected with HIV is indicative of a predominantly heterosexual mode of transmission in Botswana (McFadden, 1998:30-32; UNDP

\& Govt. of Botswana, 2000:26). The pattern, nevertheless, conceals deepseated unequal gender relations and disparities in HIV prevalence rates between younger men and women. According to the 2000 Botswana Human Development Report by the UNDP (2000:26), the risk of infection grows higher for young women in the age group 15-29 years. Three cases of 15-19-yearold HIV+ve females were reported for every one HIV+ve male case in the same age group (UNDP \& Govt. of Botswana, 2000:26).

This 3:1 ratio, as reported by the UNDP, was confirmed in this non-random sample of 116 PLWAH, with 40 women and 12 men infected in the 15-29 years of age group. Figure 2 indicates that women were infected with HIV at a much younger age than men, and other studies have suggested that HIV in Botswana is transmitted from older men to younger girls, who in turn infect boys their own age (Tlou, 2002:659; Tlou, Rantona \& Phaladze, 2001:65; UNDP \& Govt. of Botswana, 2000:26-28).

In this survey, low levels of education were reported. Not all the respondents had attended school but 52 PLWAH $(45 \%)$ had attended up to primary school level. Only 14 PLWAH (12\%) had completed their secondary education. Fewer than $10 \%$ of the participants had enjoyed tertiary education. Level of education correlated with employment data. Low levels of full-time employment were reported; only 42 PLWAH (36\%) were employed full time.

A reported monthly income of less than BWP200 (or USD40 at the time of the survey) during the preceding month was reported by 62 PLWAH $(53 \%)(\mathrm{N}=116)$ of which 42 were women $(68 \%)(n=62)$. Being HIV+ve further depletes incomes. The immediate monetary cost of HIV and AIDS to the household includes increased expenditures on health, such as travel to the government clinics or hospitals (where citizens of Botswana pay a fee of BWP2 or US $\$ 0,40$ for health care services). Patients or their relatives might also incur considerable costs when they opt to pay for second opinions about their own or their relatives' illness from traditional health care providers and/or private health care practitioners. Households might draw from their savings, dispose of assets and incur debts to finance expenditures due to rising health care costs. In addition to these direct health care related costs, incomes might dwindle due to early retirement of sick breadwinners and having to make contributions to finance relatives' funerals (MOH, 1997:22; UNDP \& Govt of Botswana, 2000:18).

Another factor that further depleted 


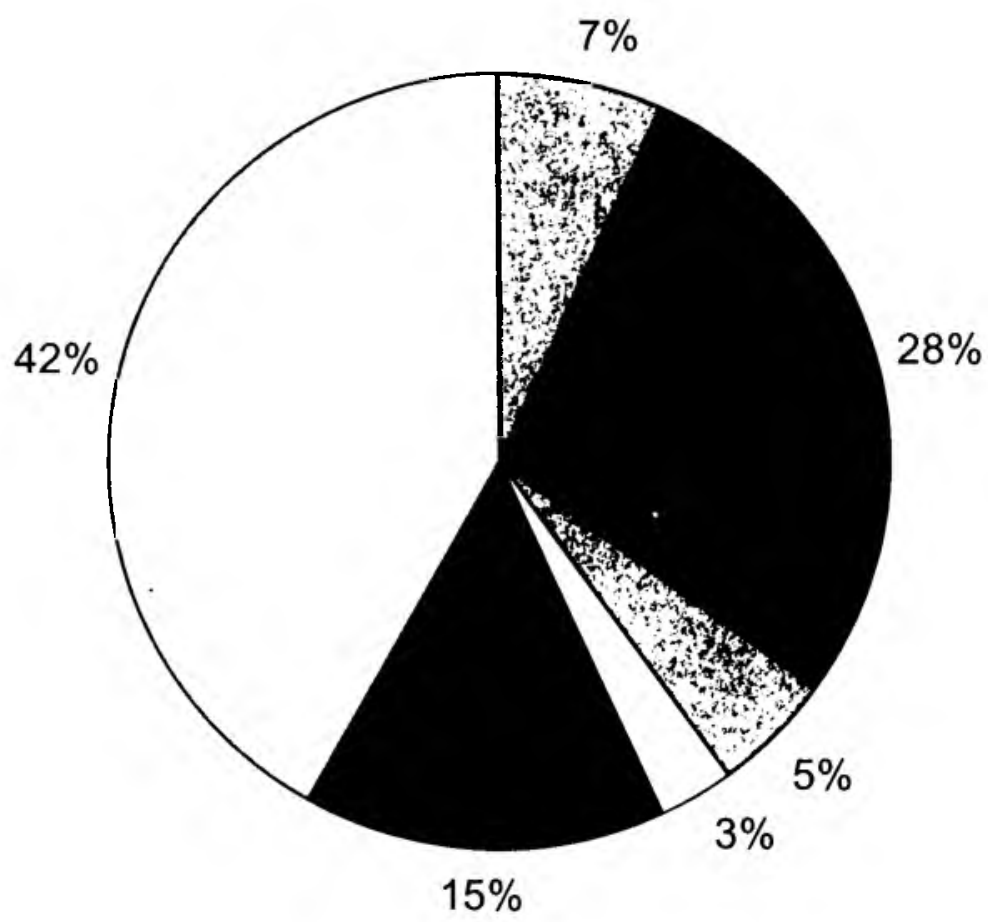

\begin{tabular}{|l|}
\hline Post-rape \\
Voluntary test \\
Child ill \\
$\square$ Partner ill \\
Pregnant \\
$\square$ Sick \\
\hline
\end{tabular}

financial resources could be identified; $15 \%$ of the survey participants reported that they looked after children of relatives or friends. This is possibly directly related to the increasing number of adults in the 20 to 40 years of age group dying and leaving orphaned children behind. Model projections indicate that by 2010 the number of children under 18 years of age, who have lost one or both parents in Botswana could rise to between 159000 and 214000 children; constituting 20\% of all children in Botswana (UNDP \& Govt. of Botswana, 2000:18-19). The government of Botswana makes an effort to ameliorate some of the hardships through social welfare measures, and providing food and school uniforms to vulnerable children in their community, according to 90 PLWAH (78\%) in the survey. However, the persistence of income inequality and poverty among its citizens, in particular the women, remains an area of concern for the Government of Botswana. Female-headed households constitute about $47 \%$ of all households having to survive on the lowest household incomes (MOH, 1995:6)

Lack of understanding of what it means to be HIV+ve was reported by $37 \%$ of the PLWAH. This was not specific to PLWAH with low incomes, although $42 \%$ of those who earned less than BWP200 reported that they did not really understand what HIV and AIDS meant.
Analysis by gender revealed that more men $(49 \%)$ had a poor understanding than women (31\%). Most PLWAH tried to educate themselves about HIV and AIDS in the place where they lived, but $26 \%$ reported that they had no access to information relevant to living with HIV and AIDS. Maslow maintained that to meet their potential people need adequate conditions for making choices, which necessitate full access to information. Maslow cautioned that useful information must not be hidden, so that people can choose without fear or social pressure (Maslow 1996b:29). The survey indicated that information was needed urgently about HIV treatment $(\mathrm{n}=114)$; welfare $(n=53)$; and counselling services $(n=42$ PLWAH).

\section{Research results about testing and disclosure}

None of the respondents had been tested for HIV as part of pre-employment testing or for insurance purposes. Most of the research participants
Figure4 Disclosure of HIV+ve status to other people

(43\%) were tested because they fell ill and their doctors wanted to know whether they were HIV+ve. Seventeen PLWAH (15\%) were tested during pregnancy. As many as $28 \%$ of the 116 PLWAH ( 10 men and 22 women), went for voluntary counselling and testing (VCT). In the early 2000 s reportedly about a third of all adults in Botswana lived with HIV, yet only a fraction presented for VCT (Donnelly 2003:1-3; UNDP \& Govt. of Botswana 2000:37). Figure 3 displays the reasons for HIV testing among the study participants. 
The data collection process of this survey depended on the participation of PLWAH who had disclosed to at least one or more persons. Many had disclosed their HIV+ve status only to the person who asked them to participate in this survey. The findings reported that $56 \%$ of the surveyed PLWAH were completely "in", meaning that they had told fewer than five people that they were HIV positive. A smaller proportion (35\%) had shared their HIV+ve status with 6 to 30 people, and were "half in/half out". Only 8 of the PLWAH surveyed stated that they had gone public and had disclosed their HIV+ve status to more than50 people. This low number was not surprising, since even in the late 1999s, in Botswana only 12 PLWAH had publicly disclosed their HIV+ve status since the first AIDS case was diagnosed in 1985 (Zuyderduin, 2001:20). Some of those PLWAH participated in this survey.

The majority of the PLWAH in this survey were diagnosed as HIV+ve between 1997 and 2000. Re-testing for HIV was common; 62 PLWAH $(53,4 \%)$ went for a repeat test and 22 PLWAH $(19 \%)$ went for more than one repeat test, indicating possible denial and/or lack of understanding about the HIV+ve diagnosis.

Of the PLWAH, $85 \%$ believed that they had become infected with HIV through heterosexual contact, while another $10 \%$ had no idea how they became HIV infected. A plethora of myths about the cause of HIV and AIDS existed, and those misconceptions could have delayed changes in behaviour and aided the spread of HIV infections (Ingstad, 1990:28-37; Steen \& Mazonde, 1999:163172; UNDP \& Govt. of Botswana, 2000:32). These misconceptions included beliefs that

\section{- $\quad$ HIV infects only promiscuous people and prostitutes. \\ - Having sex with a virgin is likened to blood cleansing and will cure AIDS.}

- $\quad$ Some traditional doctors can cure AIDS (UNDP \& Govt of Botswana, 2000:32).

\section{The need for safety and freedom from fear}

Unless PLWAH feel safe in their communities, they are unlikely to disclose their HIV+ve status for fear of ostracism due to stigmatisation.

\section{Risks of disclosure}

Unmet safety needs were expressed as fear of physical and sexual abuses after disclosure and 18 PLWAH (16\%) stated that they could not afford a lawyer but required legal assistance in connection with alleged rape/sexual assault cases. The needs theory of Maslow was helpful in understanding that both keeping the HIV+ve diagnosis a secret and telling other people were possible sources of tensions and anxieties. Where feelings of safety were affected this possibly prevented higher-level needs from emerging.

Most PLWAH were not talking about their HIV+ve diagnosis; 64 PLWAH (56\%) $(\mathrm{N}=116)$ did not feel safe and reported that most people, including those who knew them well, were completely unaware of their HIV+ve diagnosis. Their HIV+ve status was their secret. They were "in". Of those 64 PLWAH who had disclosed to fewer than 5 people, $29 \%$ were men $(n=64)$ and $71 \%$ were women $(n=64)$.

Maslow expressed his concern about keeping quiet about issues (as in not expressing or releasing emotions) and encouraged people to discuss these issues (Maslow, 1996c:41). This author cautioned that what is not used will waste away and cautioned about physical and emotional "atrophy" due to, for example, unused intelligence or unmet love needs. Maslow argued that people need to express themselves and seek releases to prevent abnormalities. Maslow advised people to use all their physical and mental capabilities to achieve discharge, gratification and perfection (Maslow, 1996c:41).

Not all PLWAH were secretive about their HIV+ve diagnosis. At the other end of the spectrum, 8 PLWAH (7\%) $(\mathrm{N}=116)$ reported their HIV+ve status to be public knowledge. They had disclosed to over 30 people and were "out". On this continuum of disclosure, 40 PLWAH $(35 \%)$ were in between these two groups, "half in and half out", and had disclosed to between 6 and 29 people. Four PLWAH did not answer this question

To measure the levels of stigma and discrimination, the PLWAH were asked about violations of their dignity, the number of times they had been insulted because of their HIV+ve status, and whether they had experienced blackmail problems. Of the PLWAH, 15\% had experienced both blackmail and insults. Blackmail was a problem for $33 \%$ of those PLWAH who had disclosed to fewer than 30 people, but verbal and physical abuse challenged PLWAH who were out with their HIV+ve status as well. Two PLWAH $(2 \%)$ had been beaten because they were $\mathrm{HIV}+\mathrm{ve}$ and 17 PLWAH (15\%) were threatened with disclosure of their HIV+ve status to people who were unaware about this fact.

Increased openness was a risk factor for verbal and physical abuse and resulted in more frequent incidents of abuse by others. Of the 8 PLWAH (6\%) $(\mathrm{N}=116)$ who had gone public with their HIV+ve status, 4 PLWAH $(50 \%)(n=8)$ had been insulted, one PLWAH (12.5\%) had been beaten and one PLWAH (12.5\%) was threatened by disclosure of his HIV+ve status to people who were unaware of this fact. An unfortunate consequence of societal stigma could be the internalisation of the negative views by those who were stigmatised. The result of self-stigma is often self-depreciation. The decision to disclose to whom becomes complex because of factors within the PLWAH as well as factors in the environment (Bunting, 1996:64; Flynn, McKeever, Spada \& GordonGarofalo, 2000:60).

Stigma causes the HIV+ve person concerned to suffer but, as Maslow pointed out, the rest of society will suffer as well. Maslow reflected on the phenomenon of an ecological balance existing in nature; benefitting not just one group but all species. From this, Maslow deduced that when disturbed conditions, such as abuse, exist between family members, they would affect not just the two people in conflict but also other family members (Maslow, 1996b:31). This insight could be transferred to the understanding of AIDS stigma, in that violations of PLWA/W's human rights harm not only the PLWH/ A but damage everyone else involved. Therefore, Maslow argued, the good for other people must be invoked, as well as the good for oneself, since there is synergy between the individual good and the good of society (Maslow, 1996b:3132).

Maslow's theory assisted in understanding the importance of a holistic approach to the care of PLWAH. 


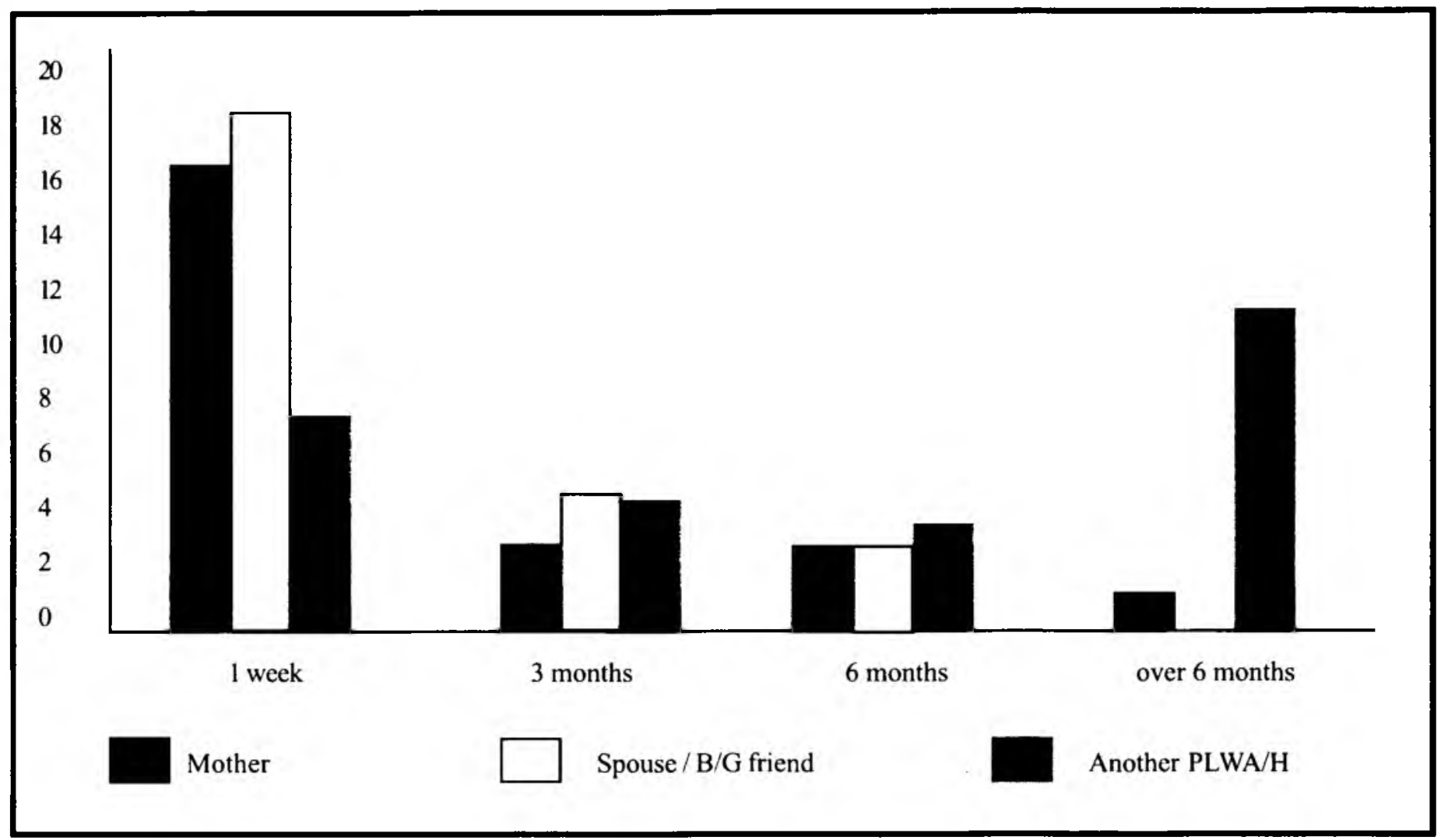

An exclusive focus on behavioural and attitude changes needed by the HIV+ve people only could assist in decreasing societal stigma.

The political climate in Botswana has been conducive to mobilising everybody, both those who know that they are HIV positive and the rest of the population. Since his election in 1998, President Mogae has led Botswana's battle against HIV and AIDS, making an effort to break the silence and denial surrounding HIV and AIDS in Botswana (Mogae, 2000: 13). Maslow supported the notion that it was important to lead by example and that other people generally mirror one's own personality, and emphasised that "the good world helps to permit the good person to be good" (Maslow, 1996b:35).

\section{Rape and HIV transmission}

This survey identified eight single women who were tested for HIV and diagnosed HIV+ve after having being raped. Reports about rape in Botswana by a local NGO, Women Against Rape in Maun, suggested that - despite a marked increase in the number of reported rape cases - conviction rates have remained extremely low (UNDP \& Govt. of Botswana, 2000:31). Of the eight HIV+ve women raped, five indicated that if they were able to get a lawyer free of charge they would use legal assistance in dealing with this situation. Police and court records show that two-fifths of Botswana's rape cases involve girls younger than 16 years, but data on the relationship between abuse and HIV transmission through rape are largely absent (UNDP \& Govt. of Botswana, 2000:31). None of the women raped were on ARVs. Four of the women were helped by their families to cope; three of the women were supported by another PLWAH; and one woman was supported by a nurse. Five of the women had told their parents about their HIV+ve status and had received supportive counselling during the previous three months. All eight these PLWAH would like to be visited at home by another PLWAH if that were possible. One of these women reported that she went public to tell others what had happened to her.

\section{The need for love and belongingness}

Love and belongingness were identified as third-level needs in Maslow's Hierarchy of Human Needs Theory (see figure 1). Nearly $70 \%$ of the 116 PLWAH reported that they were not in an intimate relationship. Of those who were, 18 PLWAH (16\%) reported that their partners were also HIV+ve.

Nearly a third of the PLWAH had experienced multiple deaths within their families during the year preceding the survey. Of the 112 PLWAH who had done so, $27 \%$ had lost three or more close family members during 1999. Only four PLWAH reported that they had not lost close family members.

This might have contributed to additional tensions due to unresolved grieving processes. Supportive counselling was received three months preceding the completion of the questionnaire by 71 PLWAH $(61 \%)(\mathrm{N}=116)$, and 57 PLWAH $(47 \%)$ had access to a support group. It was very important for the 58 female PLWAH $(75 \%)(n=77)$ across all age groups to be in an all-female support group where they could discuss their problems and concerns with peers. However, despite availability of peer support, there was evidence that Botswana was indeed experiencing a crisis and that the death toll was rising (Mbogori, 1998:2; Mogae, 2000:13).

Nearly half of all the PLWAH surveyed $(48 \%)$ had not told their parents about their HIV+ve status. Seventeen PLWAH (15\%) explained that they did not tell their parents because they were frightened of how their elderly parents would react. The reason stated most often was that the PLWAH feared they would be rejected by their family. These PLWAH 


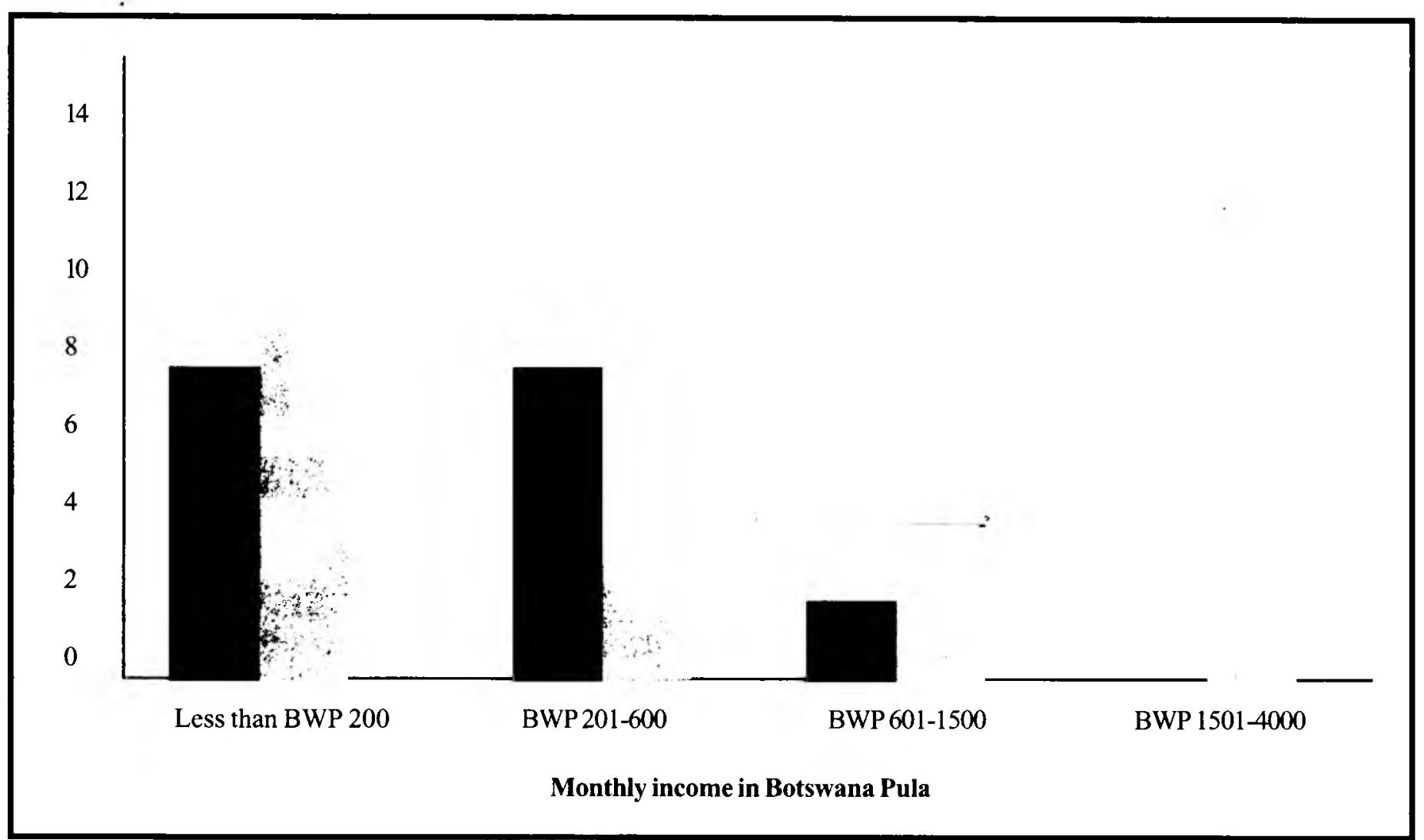

decided to avoid ostracism or stigmatism, even when they forfeited appropriate psychosocial support as a consequence of these actions.

Many of the PLWAH who had anticipated negative reactions by those they informed about their HIV status actually found acceptance. The first persons of choice who were told of their HIV+ve status were: another PLWAH (25\%); the spouse or boy/girlfriend $(23 \%)$ or their mother $(21 \%)$. When they revealed their HIV+ve diagnosis to another PLWAH, their partner or their mother, an encouraging $64 \%$ reacted to the news in a supportive manner, according to the PLWAH. Sixty PLWAH $(52 \% ; n=116)$ informed the first person within a week after the HJV+ve diagnosis had been made. Twelve PLWAH (37\%; $=33)$ took longer than three months to disclose and had not told their sex partner during the preceding year that they were HIV+ve. However, 17 PLWAH $(15 \% ; n=116)$ took longer than six months before telling that first person (see figure 5).

Peer support was important in promoting disclosure; of the 17 PLWAH who had not told anybody about the HIV+ve status for more than six months, $70 \%$ eventually told other PLWAH about their HIV+ve diagnosis. Thirteen PLWAH $(76 \%)(n=17)$ who had kept their HIV+ve status a secret for a longer time reported that other PLWAH were the most important people for them to help them cope with the HIV+ve diagnosis.

The persons most important for helping the PLWAH to cope with the HIV infection were: other PLWAH according to 69 PLWAH $(60 \%)$ (20 men and 49 women); family according to $17 \mathrm{PLWAH}$ $(15 \%)(\mathrm{N}=116)$; and the church according to 10 PLWAH $(9 \%)$.

\section{Need for peer support}

According to Misovich, Fisher and Fisher (1997:95-123), successful prevention of HIV transmission is based on three components: information, motivation and behavioural skills. Dialogue with wellinformed peers can validate PLWAH' correct information or indeed correct their misinformation, express positive attitudes and norms for behaviour and can provide role models for the development of behavioural skills. These researchers argued that it is likely that AIDS prevention interventions making use of similar (peer) expertise will be more effective than interventions without such leaders (Misovich et al., 1997:95123). This was a challenge in Botswana during 2000, since peer support was not available to $16 \%$ of the PLWAH. These PLWAH did not know another PLWAH where they lived, and $20 \%$ reported that they could not phone another PLWAH within 24 hours if they had a problem related to their HIV+ve status. Sixty-one PLWAH (53\%) reported that they knew between one and five PLWAH, and 22 PLWAH (19\%) reported that they knew six or more.

\section{The need for esteem and care}

Believing that others think well of us enhances self-esteem, and motivational support by caregivers encourages people to take care of themselves (Cohen \& Syme, 1985:67-68). Since health cannot be defined by PLWAH as the narrow condition of not being ill, PLWAH need support to view health as a resource for living or a resource for power. Maslow thought of people as autonomous, active responsible agents and that fate, biological injustice and the like may set limits but that within those limits a person could either achieve very little, or do a great deal (Maslow, 1996a:66). These actions were placed in the realm of free will and choice and therefore of responsibility. Maslow believed strongly that one could be all that one is capable of being or be less than one is capable of being, an active agent or a helpless, whining pawn. Being less would, according to Maslow, lead to intrinsic guilt because of having violated or 
betrayed one's own higher nature (Maslow, 1996a:66-67).

Denial was also recognised as a defence mechanism in coming to terms with a HIV+ve diagnosis (Kalichman, Sikkema \& Somalai, 1996:589-599; Lazarus, 1993:234-240; Moneyham, Hennessey, Sowell. Demi. Seals \& Mizuno, 1998:351362). This coping mechanism serves to allow no more emotional pain than is tolerable and can be recognised as healthy defensiveness for a limited time, but will ultimately lead to ill health if not resolved.

However, both the state of guilt and denial and perceptions of possible negative reactions communicate selfstigma. The assessment by the PLWAH of what others might do or say is not necessarily a reflection of what is happening in reality. The majority of the PLWAH in this survey, $73(63 \%)$, always told nurses and doctors that they were HIV+ve and received care. Guidance and encouragement from health care providers to engage in health-promoting self-care actions to prevent or treat opportunistic infections such as TB and to adopt healthy lifestyles were very important. Self-care requisites of PLWAH included testing for HIV and help with decision making about subsequent disclosure of the HIV+ve diagnosis to family and health care providers. The PLWAH may need time to accept their HIV+ve diagnosis, and the fact that 36 PLWAH (21\%) pretended not to be HIV+ve, or did not say anything about their HIV+ve status because they did not trust their nurse, could indicate that these respondents were still in the phase where they required time to accept their $\mathrm{HIV}+\mathrm{ve}$ status.

Having respect for each other in caring relationships has been identified as a precondition for effectiveness in helping relationships in general and between caregivers and HIV+ve people in particular (Faugier \& Sargeant, 1997:222230; Powell-Cope, 1994:324-330; Roberts \& Krouse, 1990:30-36).

Because of the fact that HIV is predominantly sexually transmitted, guaranteeing confidentiality has been the foundation of all HIV prevention and health promotion strategies that aimed at lasting behavioural change, but has been subject to debate, since the ethical dilemmas associated with the rights and duties of PLWAH were not always well understood (Gibney, DiClemente \&
Vermund, 1999:88; Hayter, 1997:11621166). In 1999, Mann (1999:217) postulated that participation in HIV testing and counselling activities increased when HIV testing facilities instituted anonymous testing. However, in Botswana uptake of HIV testing remains low (Bara, 2002:1-9; Donnelly, 2003:1-3; Talbot, Kenyon, Halabi, Moeti, More \& Binkin, 2000:1 156-1163).

Informed consent is the basis for the trusting relationship between health care providers and patients. Studies done in the USA and the UK during the last part of the 1990s provided examples of the negative effects of forced disclosure: people losing their jobs and their houses and being ostracised by their family and friends (Ingram \& Hutchinson 1999:93; Kimberley, Serovich \& Greene, 1995:316; Mann et al., 1999:17). Forced disclosure was even more dangerous for women, who might have to deal with domestic violence and abandonment by their father or male partner or husband (UNDP \& Govt of Botswana, 2000:28). Nevertheless, in Botswana, doctorpatient confidentiality is not absolute and disclosure may be justified in certain circumstances. Botswana applies the principle of "shared confidentiality". This principle implies that doctors in Botswana shall inform those who need to know of the medical condition of the patient before appropriate health and social welfare care can be provided. The people who need to know include

- $\quad$ all persons who come into close
regular contact, and
all those living with the HIV+ve
person (MOH, 1997:62).

In the Second Medium Term Plan on HIV and AIDS, 1997-2002, a need for clarification of Botswana's principle of "shared confidentiality" was identified. Not much is known about how doctors in Botswana deal with the demands of the shared confidentiality principle placed on them in their daily practice (MOH, 1997:62; MOH, 1998:12). If patients in Botswana were told about situations in which confidentiality could be breached, the prevailing attitude that the medical profession could not be trusted, as reported by $21 \%$ of the 116 PLWAH in the 2000 survey, might not occur.

In Botswana, specialised care was offered to HIV+ve women at the local clinics.
This programme aimed to prevent transmission of HIV from the HIV+ve mother to child during pregnancy, birth or through breastfeeding by giving the HIV+ve mother short-term therapy with one type of ARV (Hankins, 2000:57-62). However, 53 PLWAH (46\%) $(\mathrm{N}=116)$ in the survey, aware of low uptake of this service in Botswana, reportedly thought that few HIV+ve women agreed to participate in the PMTCT programme and take AZT (ARV drug, monotherapy) during pregnancy because the HIV+ve women feared disclosure when not breastfeeding their babies. An alternative reason could be, according to 32 PLWAH $(28 \%)$, the lack of understanding of prevention of vertical transmission of HIV by pregnant women.

\section{Tuberculosis}

Tuberculosis and HIV and AIDS are often referred to as the twin epidemics. A postmortem study on those who died of AIDS in $1997 / 1998$ indicated that about $44 \%$ of adults who died of AIDS also had TB (Lockma, Sheppard, Braden, Mwasekega, Woodley, Kenyon, Binkin, Steinman, Monthso, Kesupile-Reed, Hirschfield, Notha, Moeti \& Tappero, 2001:10421047). In 1995 it was reported that the true picture of TB/HIV co-infection was not known, but four years later, in 1999, it was estimated that $50-80 \%$ of Botswana's TB patients were co-infected with HIV (MOH, 1995:13; UNDP \& Govt of Botswana 1999:20-21). Botswana implemented a TB prevention programme for HIV+ve people, encouraging PLWAH to prevent latent TB from becoming an acute infection when the immune system is weakened started in 1999 (BOTUSA 1999:26; Ridzon \& Mayanja-Kizza, 2002:382) To prevent TB, 21 PLWAH $(18 \%)$ were on a course of Isoniazid tablets that they had to take daily (at home) for six months. The situation is increasingly serious as Botswana in 2002 reported one of the highest TB infection rates in the world, with about one in every 200 citizens of Botswana having active TB (Talbot et al., 2002:311).

In the 2000 survey 33 PLWAH (29\%) (12 men and 21 women) reported that they were suffering from TB and were on Direct Observed Treatment Strategy (DOTS), taking their medications daily to cure their TB infections. Two-thirds of the PLWAH with active TB were satisfied with the support received from the government health care system and $60 \%$ always told their nurses that they were HIV+ve. An 
association between poverty, resulting in malnutrition and overcrowding, and TB was identified in the National TB programme of Botswana (MOH, 1995:8). In the 2000 survey, incomes and TB were linked, since $64 \%$ of the 33 PLWAH with TB belonged to the very low income group, making it difficult for these TB sufferers to eat proper meals (see figure $6)$.

\section{Antiretroviral treatment (ARVs)}

During 2000 when the survey was conducted, the government of Botswana had not yet included ARVs in basic care services to PLWAH. Access to ARVs was confined to the group of persons who could afford medical aid schemes, participated in clinical research trials or paid cash for the ARVs. This survey during 2000, one year prior to the launch of the national ARV programme MASA, found that a small group of five PLWAH - all women - $(4 \%)(n=116)$ were taking ARVs, whilst 111 PLWAH (96\%) were not taking ARVs. This situation changed dramatically during 2002 with the launch of the MASA (meaning "early dawn") ARV programme, when thousands of AIDS patients in Botswana enrolled for ARV treatment free of charge (Zuyderduin, 2004:8-10).

\section{Depression, tiredness and anxiety about health}

Thirteen PLWAH, four men and nine women, were very worried about their health, felt very depressed, had been very tense and had had no energy during the month preceding the survey. Of these 13 PLWAH in poor health, three PLWAH $(23 \% ; n=13)$ were public about their HIV+ve status and had disclosed to over 30 people. Twelve PLWAH (92\%) would have liked to get support through home visits from another PLWAH, and six PLWAH $(46 \%)$ identified another PLWAH as a person who could help them to cope. Three PLWAH (23\%) reported that nurses were instrumental in helping them to cope with their HIV+ve diagnosis.

The findings of this survey were in agreement with two other studies. In 1999, 48 low-income women attending HIV clinics in the USA were studied. The researchers listed 349 different needs that could be subdivided as follows: psychosocial needs (32\%); physical needs $(14 \%)$; service and maintenance needs $(13 \%)$; and financial and legal needs (11\%) (Bunting, Bevier \& Baker, 1999:41). Another US social work study examined the psychosocial needs of 12 HIV+ve women through in-depth interviews. An analysis of the data indicated a variety of needs, including needs for information and support, assistance from health care professionals, planning for the present and future of their children, financial assistance and adjustment to loss of employment, and finding accommodation (Hobbs Leenerts \& Magilvy, 2000:58-75).

\section{Self-actualisation and transcendence}

Despite the deficiencies in the fulfilment of safety, belonging and esteem needs, positive attitudes were reported by the majority, over $73 \%$, of the 116 PLWAH. They did not believe the HIV+ve diagnosis was a death sentence and they were optimistic about the future and expressed their will to live. The entire model of humanistic psychology and selfactualisation rests on the assumption that the person wants to live (Maslow, 1996b:26). The traumatic impact of living with AIDS has usually been the focus in studies of PLWAH. However, from 1994 onwards, evidence was beginning to suggest that it was possible that PLWAH could lead meaningful and productive lives (Collins, Kanouse, Gifford, Senterfitt, Schuster, McCaffrey, Shapiro \& Wenger, 2001:351-360; Coward, 1994:331-336; McWilliam, Stewart, Brown-Belle, Desai \& Coderre, 1996:1-15; Mellors, Erlen, Coontz \& Lucke, 2001:235246; Metcalfe et al., 1998:30-34; Schwartzberg, 1994:593-602).

In a qualitative study of five PLWAH, Mellors et al. (2001:236) postulated that through introspection and concern about others and their well-being, people can gain understanding about themselves and move beyond themselves. The process of self-transcendence has the potential to influence the course of HIV and AIDS, and PLWAH might be able to forge rewarding and in some cases lifetransforming meaning out of their situation (Mellors et al., 2001:237). Fortythree PLWAH (37\%) (N=116) reportedly had experience with overcoming big difficulties in their lives other than their HIV+ve status. Seventy-six PLWAH $(66 \%)$ were providing support to others who were in difficult situations. The study by Mellors et al. offered insight into how PLWAH transcend the emotional and physical suffering of their illness and how former ways of thinking and being that had limited their ability to integrate the demands of living with HIV and AIDS were transcended (Mellors et al. 2001:237). The attitudes of the participating PLWAH towards being HIV+ve were assessed and 19 PLWAH $(16 \%)$ reported that they felt ambivalent - sometimes they accepted it; sometimes they denied the HIV+ve diagnosis. However, an encouraging $84 \%$ of the PLWAH that participated in the survey reported optimism and positive attitudes towards living with HIV and AIDS; planning for their future.

\section{Caring for others}

Maslow believed that basic need gratification must come from interpersonal relations and the wider society. A good society would encourage desirable traits such as affection, altruism, friendliness and kindness (Maslow, 1996f:83-84). Despite their own challenges in life, the surveyed PLWAH reported that they took care of others who were ill. Compassion was shown to others and $47 \%$ of the PLWAH were caring for a sick family member or neighbour during the month preceding the survey.

Maslow demonstrated that emotionally healthy persons showed that when they behaved unselfishly, this behaviour tended to be a phenomenon of personal abundance stemming from relative basic gratification (Maslow, 1996e:113). This might be one possible reason why 35 PLWAH (30\%) in the survey reported that they were willing to be trained as buddies. Not all PLWAH were prepared to care for and support others within a buddy system; 19 PLWAH $(16 \%)(n=116)$ would be buddies if paid, and 50 PLWAH (43\%) were unsure as to wether or not they wanted to be trained as buddies.

Maslow argued that as we are born we have an intrinsic need to experience the highest values such beauty, truth justice and so on. These higher needs are biologically rooted just as are our lower needs for food and safety (Maslow, 1996d:97). The notion that people have the ability and motivation to improve during their lifetime, and that society is improvable, was important in understanding some of the findings of the survey. Maslow postulated that meeting higher values not only prevents certain forms of illnesses such as neurosis, hopelessness and the like, but motivates people to not merely accept 
the world as it is but strive to better their world(Maslow, 1996d:96-98).

\section{Conclusion}

This survey indicated that there were opportunities for sustaining, scaling up and improving HIV and AIDS care and support for PLWAH. Maslow's needs theory was valuable in explaining how higher needs emerge when lower needs are gratified. The theory suggested that it was not only possible to strive for growth and higher values but that doing so would actually help others and oneself. Maslow predicted that efforts to be in this world and function to one's highest capabilities would contribute to deep feelings of inner happiness and fulfilment.

The PLWAH listed a number of desired services, programmes, and interventions that needed to be met by other people. The PLWAH identified the need for access to:

$\begin{array}{ll}\text { - } & \text { education about what a HIV+ve } \\ \text { diagnosis means } \\ \text { nutrition advice } \\ \text { education about basic } \\ \text { treatment issues } \\ \text { - } \\ \text { access to ARVs } \\ \text { long-term supportive peer } \\ \text { counselling } \\ \text { TB prevention }\end{array}$

However, the centre of attention was not only on deficiencies, the surveyed PLWAH had something to offer as well. The PLWAH stated their willingness to be involved in care and support efforts and demonstrated their enthusiasm and motivation to support other PLWAH in Botswana.

The 2000 survey was a unique survey of needs of people who had up to then been silent about their HIV+ve status. The survey explored how PLWAH understood the meaning of "living with HIV". The PLWAH were asked about possible negative and positive experiences linked to their HIV+ve status. Some of the PLWAH were not yet prepared to disclose their HIV+ve status to more people but were able through an appropriately designed survey to express their need for guidance on how to live well and their need for increased access to social support. The PLWAH stated that involvement in matters that affected their own health and well-being was essential.

This survey provided important results as by 2003, a section of the PLWAH community had indeed translated words into action and were involved in the design of care and support by and for PLWAH. Members of COCEPWA had during 2001 and 2002 adapted a US buddy programme into a buddy programme for African PLWAH in Botswana. A number of buddies were trained in Boswana. During 2003 Botswana's communitybased buddy-support programme was adopted by four other countries in Southern Africa in an attempt to enhance the quality of the life of PLWAH in these countries.

\section{List of references}

BARA, H 2002: Total community mobilisation survey 2002: myths and misconceptions on HIV/AIDS among field officers. Gaborone: Total Community Mobilisation.

BARROSO,J \& POWELL-COPE, GM 2000: Metasynthesis of qualitative research on living with HIV infection. Qualitative Health Research, 10(3):340353.

BERER, M 2000: Women and HIV/AIDS: reproductive and sexual health. London: Spiderweb

BOTUSA 1999: The BOTUSA project: a collaboration of the ministry of health, Botswana and the US Centers for disease control and prevention. Gaborone: Government Printer.

BOWSER, BP \& SIEBER, JE 1993: AIDS prevention research: old problems and new solutions (In: Renzetti, CM \& Lee, RM Eds. 1993: Researching sensitive topics. London: Sage.

BUNK, B P \& GIBBONS, F X 1997: Health, coping and well-being: perspectives from social comparison theory. London: Lawrence Erlbaum

BUNTING, SM 1996: Sources of stigma associated with women with HIV. Advances in Nursing Science, 19(2):6473.

BUNTING, SM, BEVIER, DJ \& BAKER, SK 199: Poor women living with HIV: self-identified needs. Journal of Community Health Nursing, 16(1):41-52.
BURNS, N \& GROVE, SK 2001: The practice of nursing research: conduct, critique \& utilization. $4^{\text {th }}$ edition. Philadelphia: WB Saunders.

COHEN, S \& SYME, LS 1985: Social support and Health. New York: Academic Press.

COLLINS, RL, KANOUSE, DE, GIFFORD, AF, SENTERFITT, JW, SCHUSTER, MA, MCCAFFREY, DF, SHAPIRO, MF \& WENGER, NS 2001: Changes in health promoting behavior following diagnosis with HIV: prevalence and correlates in a national probability sample. Health Psychology, 20(5):351360 .

COWARD, D 1994: Meaning and purpose in the lives of persons with AIDS. Public Health Nursing, 11(5):331336.

DONNELLY, J 2003: Reluctance to test slows Botswana's AIDS fight. http:// www.boston.com/news/world/africa/ articles/2003/11/08/reluctance

ERLEN, JA \& MELLORS, MP 1999: Adherence to combination therapy in persons living with HIV: balancing the hardships and the blessings. Joumal of the Association of Nurses in AIDS Care, 10(4):75-84.

ESSEX, M, MBOUP, S, KANKI, P, MARLINK, R \& TLOU, SD1993: AIDS in Africa. New York: Kluwer.

FAUGIER, J \& SARGEANT, M 1997: Stigma: its impact on professional responses to the needs of marginalised groups. Nursing Times: Research, 2(3):220-230

FLASKERUD, JH, LESSER, J, DIXON, E, ANDERSON, N, CONDE, F, KIM, S, KONIAK-GRIFFIN, D,STREHLOW,A, TULLMANN, D \& VERZEMNIEKS, I 2002: Health disparities among vulnerable populations. Nursing Research, 51(2):74-85.

FLYNN, M, B, MCKEEVER, J, L, SPADA, T \& GORDON-GAROFALO, V 2000: Active client participation: an examination of self-empowerment in HIV/ AIDS case management with women. Journal of the Association of Nurses in AIDS Care, 11(3):59-68.

GIBNEY, L, DICLEMENTE, RJ \& 
VERMUND, SH 1999: Preventing HIV in developing countries: biomedical and behavioral approaches. New York: Plenum.

HANKINS, C 2000: Preventing motherto-child transmission of HIV in developing countries: recent developments and ethical implications. (In: Berer, M 2000: Women and HIV/ AIDS: reproductive and sexual health. London: Spiderweb. pp57-62).

HAYTER, M 1997: Confidentiality and the acquired immune deficiency syndrome (AIDS): an analysis of the legal and professional issues. Journal of Advanced Nursing, 25(-):1162- 1166.

HOBBS LEENERTS, M \& MAGILVY, $J$, K 2000: Investing in self-care: a midrange theory of self care grounded in the lived experience of low-income HIVpositive white women. Advances in Nursing Science, 22(3):58-75.

HOFFMAN, E 1996: Future visions: the unpublished papers of Abraham Maslow. Thousand Oaks: Sage

INGRAM, D \& HUTCHINSON, SA 1999: HIV-positve mothers and stigma. Health Care for Women International, 20(1):93-103.

INGSTAD, B 1990: The cultural construction of AIDS and its consequences for prevention in Botswana. Medical Antropology Quarterly, 4(-):28-37.

JIRAPAET, V 2000: Effects of an empowerment program on coping, quality of life, and maternal role adaptation of Thai HIV-infected mothers. Journal of the Association of Nurses in AIDS Care, 11(4):34-45.

KALICHMAN, SC, SIKKEMA, K \& SOMALAI, A 1996: People living with HIV infection who attend and do not attend support groups: a pilot study of needs,characteristics and experiences. AIDS Care, 8(-):589-599.

KIMBERLEY, JA, SEROVICH, JM \& GREENE, K 1995: Disclosure of HIVpositive status: five women's stories. Family Relations, 44(316-322.

KVITZ, FJ, CRITTENDEN, KS, MADURA, KJ \& WARNECKE, RB 1994: Use and effectiveness of buddy support in a self-help smoking cessation programme. American Journal of Health Promotion, 8(3):191-201.

LAZARUS, RS 1993: Coping theory and research: past, present and future. Psychosomatic Medicine, 55(4):234-247.

LOCKMA, S, SHEPPARD, J, BRADEN, C, MWASEKEGA, M, WOODLEY, C, KENYON, T, BINKIN, N, STEINMAN, M,MONTHSO,F,KESUPILE-REED,M, HIRSCHFIELD,C, NOTHA, M,MOETI, T \& TAPPERO, J 2001: Molecular and conventional epidemiology of Mycobacterium tuberculosis in Botswana: a population based prospective study of 301 pulmonary tuberculosis patients. Journal of Clinical Microbiology, 39(3):1042-1047.

MANN, J, GRUSKIN, S, GRODIN, M \& ANNAS, G 1999: Health and human rights. New York: Routledge.

MASLOW, AH 1996a: Biological injustice and free will (In: Hoffman, E 1996: Future visions: the unpublished papers of Abraham Maslow. Thousand Oaks: Sage. pp64-69).

MASLOW, AH 1996b: Critique of selfactualization theory (In: Hoffman, E 1996: Future visions: the unpublished papers of Abraham Maslow. Thousand Oaks: Sage. pp26-32).

MASLOW, AH 1996c: The health implications of peaks-to-completion (In: Hoffman, E 1996: Future visions: the unpublished papers of Abraham Maslow. Thousand Oaks: Sage. pp39-41).

MASLOW,AH 1996d: Higher motivation and the new psychology (In: Hoffman, E 1996: Future visions: the unpublished papers of Abraham Maslow. Thousand Oaks: Sage. pp88-89).

MASLOW, AH 1996e: Is human nature basically selfish? (In: Hoffman, E 1996: Future visions: the unpublished papers of Abraham Maslow. Thousand Oaks: Sage. pp 107-114).

MASLOW, AH 1996f: What is the essence of human nature? (In: Hoffman, E 1996: Future visions: the unpublished papers of Abraham Maslow. Thousand Oaks: Sage. pp47-51).

MASLOW, AH 1999: Toward a psychology of being. $3^{\text {rd }}$ ed. New York: John Wiley.
MBOGORI, EL 1998: Is it not time to declare a regional disaster?

MCFADDEN, P 1998: Re-visiting HIV/ AIDS in the context of African female sexuality. Southern African Political \& Economic Monthly (SAPEM), 11(8):3032.

MCWILLIAM, C, STEWART, M, BROWN-BELLE, J, DESAI, $K$ \& CODERRE, $P$ 1996: Creating health with chronic illness. Advances in Nursing Science, 18(3):1-15.

MELLORS, M, ERLEN, J, COONTZ, P \& LUCKE, K 2001: Transcending the suffering of AIDS. Journal of Community Health Nursing, 18(4):235-246.

METCALFE, KA, LANGSTAFF, JE, EVANS, SJ, PATERSON, HM \& REID, JL 1998: Meeting the needs of women living with HIV. Public Health Nursing, 15(1):30-34.

MINISTRY OF HEALTH 1999: Evaluation of the Botswana national tuberculosis (TB) programme. Gaborone: Government Printer.

MINISTRY OF HEALTH 1995: National tuberculosis programme manual. Gaborone: Government Printer.

MINISTRY OF HEALTH 1997: Botswana HIV and AIDS: second medium term plan 1997-2002: NACP 38.Gaborone: Government Printer.

MINISTRY OF HEALTH 1998: Botswana national policy on HIV/ AIDS.Gaborone: Government Printer.

MISOVICH,SJ, FISHER,JD \& FISHER, WA 1997: Social comparison processes and AIDS risk and AIDS preventive behaviour (In: Bunk, B P \& Gibbons, F X 1997: Health, coping and well-being: perspectives from social comparison theory. London: Lawrence Erlbaum. pp95123).

MOGAE, FG 2000: Botswana's president: 'our people are crying out for help'. AIDS Policy and Law, 15(18):13.

MOH - see Ministry of Health

MONEYHAM, L, HENNESSEY, M, SOWELL, RL, DEMI, A, SEALS, B \& MIZUNO, Y 1998: The effectiveness of coping strategies used by HIV- 
seropositive women. Research in Nursing and Health, 21(4):351-362.

MURPHY,LM, KORANYI, K, CRIM, L \& WHITED, S 1999: Disclosure, stress, and psychological adjustment among mothers affected by HIV. AIDS Patient Care and STDs, 13(2):111-118.

NACA - see National AIDS Coordinating Agency

NANNIS, ED, PATTERSON, TL \& SEMPLE, SJ 1997: Coping with HIV disease among seropositive women:psychosocial correlates. Women and Health, 25(1):1-22.

NATIONALAIDS COORDINATING AGENCY 2002: Botswana 2002 second generation HIV/AIDS surveillance. Technical Report: Gaborone: Government Printer.

PIOT, P, BARTOS, M, GHYS, PD, WALKER, N \& SCHWARLANDER, B 2001: The global impact of HIV/AIDS. Nature, 410(6831):968-975.

PLATZER, H \& JAMES, T 1997: Methodological issues conducting sensitive research on lesbian and gay men's experiences of nursing care. Journal of Advanced Nursing, 25(3):626633.

POWELL-COPE, GM 1994: Family caregivers of people with AIDS: negotiating partnerships with professional health care providers. Nursing Research, 43(6):324-330.

RENZETTI, CM \& LEE, RM 1993:Researching sensitive topics. London: Sage.

RIDZON, R \& MAYANJA-KIZZA, H 2002: Tuberculosis (In: Essex, $M$, Mboup, S, Kanki, P, Marlink, R \&Tlou, SD1993: AIDS in Africa. New York: Kluwer. pp 373-386).

ROBERTS, S \& KROUSE, H 1990: Negotiation as a strategy to empower self-care. Holistic Nursing Practice, $4(2): 30-36$.

SCHWARTZBERG, S 1994: Vitality and growth in HIV-infected gay men. Social Science \& Medicine, 38(4):593-602.

SHERMAN, DW 1999: Essential information for providing quality care to patients with HIV/AIDS. Journal of the New York State Nurses Association, 30(2):8-19.

STEEN, T \& MAZONDE, G 1999: Ngaka ya setswana, ngaka ya sekgoa or both? Health seeking behaviour in Batswana with pulmonary tuberculosis. Social Science \& Medicine, 48(0): 163-172.

SWINDELLS, S, MOHR, J, JUSTIS, J, BERMAN, S, SQUIER, C, WAGENER, M \& SINGH, N 1999: Quality of life in patients with human immunodeficiency virus infection: impact of social support, coping style and hopelessness. International Journal of STD and AIDS, 10(6):383-391.

TALBOT, E, KENYON, T, HALABI, S, MOETI, T, MORE, K\& BINKIN, N 2000: Knowledge, attitudes and beliefs regarding tuberculosis preventive therapy for HIV-infected persons, Botswana 1999. International Journal of Tuberculosis Lung Disease, 4(12):11561163.

TALBOT, E, KENYON, T, MOETI, T, HSIN, G, DOLEY, L, EL-HALABI, S \& BINKIN, N 2002: HIV risk factors among patients with tuberculosis- Botswana 1999. International Journal of STD and AIDS, 13(311-317.

TLOU, SD 1996: Empowering older women in AIDS prevention: the case of Botswana. Southern African Journal of Gerontology, 5(2):27-32.

TLOU, SD 2002: Gender and HIV/AIDS in AIDS in Africa by Essex, M, Mboup, S, Kanki, P, Marlink, R \&Tlou, S D. $2^{\text {nd }}$ ed. New York: Kluwer

TLOU, SD, RANTONA, K \& PHALADZE, N 2001: Health care, gender and HIV/AIDS: prevention, treatment and care. Gaborone: Government Printer.

TSEVAT, J, SOLZAN, J, KUNTZ, K, RAGLAND, J, CURRIER, J,SELL, R\& WEINSTEIN, MC 1996: Health values of patients infected with human immunodeficiency virus. Medical Care, $34(1): 44-57$.

UNAIDS - see United Nations Programme on HIV/AIDS

UNDP \& GOVT OF BOTSWANA see United Nations Development Program and Government of Botswana
UNITEDNATIONSPROGRAMME ON HIV/AIDS 2002: Facts sheets 2002: high income countries. Geneva:UNAIDS.

UNITED NATIONS DEVELOPMENT PROGRAM AND GOVERNMENT OF BOTSWANA 2000: Botswana human development report 2000: towards an AIDS-free generation.Gaborone: Government Printer.

ZUYDERDUIN，J 2001: Needs assessment report: people living with HIV/AIDS in Botswana.Gaborone: The Coping Centre for People Living with HIV/AIDS (COCEPWA).

ZUYDERDUIN, JR 2004: The buddy system of care and support for and by women living with HIV/AIDS in Botswana. Pretoria: University of South Africa (D Litt et Phil thesis). 